\title{
Asimetrías craneofaciales: análisis radiográfico en los planos frontal y basal en individuos de ambos sexos de 18 a 22 años
}

\section{Craniofacial asymmetry: radiographic analysis in the frontal and transverse planes in subjects aged 18 to 22 years of both sexes}

\author{
M.C. Fucini', J.E. Baudo', A.C. Bencini2, L.A. Sosa3, L.M. Etchegoyen', C.G. Fornés, L. Solari3, \\ E.I. Milat ${ }^{4}$
}

\begin{abstract}
Resumen: El objetivo de este trabajo fue determinar el tipo y magnitud de asimetrías craneofaciales a partir del análisis cefalométrico de planos múltiples. Se trabajó con una muestra de 207 individuos de ambos sexos de 18 a 22 años, que fueron radiografiados en plano frontal con incidencia posteroanterior. Sobre cada radiografía se realizaron tres calcos tomando como referencia estructuras en tres planos: A (superficial), B (medio) y C (profundo). Se trazó una línea media virtual. Las líneas medias reales fueron superpuestas comparadas con la línea media virtual, determinándose así la dirección y la magnitud de la desviación en cada plano. Estos individuos fueron radiografiados en plano basal. Sobre cada radiografía se realizaron tres calcos tomando como referencia estructuras en tres planos diferentes: A (orbital), B (maxilar) y C (mandibular). Se trazó una línea media virtual que se comparó con la línea media real. Plano frontal: Los resultados indicaron una mayor frecuencia de desviación hacia la derecha en los tres planos, siendo estas desviaciones mayores en el plano B, respecto de los planos $C$ y $A$ tanto en dirección como en magnitud. Plano basal: Los resultados indicaron una mayor frecuencia de desviación hacia la izquierda en los tres planos, siendo estas desviaciones mayores en el plano $C$, respecto de los planos $B$ y $A$ tanto en dirección como en magnitud. Estos resultados muestran la generalidad de las asimetrías craneofaciales y resaltan la importancia de su estudio para la detección de patologías de crecimiento craneofacial.
\end{abstract}

Palabras clave: Asimetría; Craneofacial; Desviación.

Recibido: 24.04 .05

Aceptado: 17.12 .08

1 Profesora Adjunta de Radiología y Fisioterapia de la Facultad de Odontología de la Universidad Nacional de La Plata. Buenos Aires, República Argentina.

2 Presidente de la Sociedad Argentina de Cirugía y Traumatología Bucmaxilofacial; Jefe del servicio de Odontología y Cirugía Bucomaxilofacial del Hospital San Juan de Dios de La Plata; Profesor Titular de la Cátedra Cirugía Ortognática de la Facultad de Odontología de la Universidad Nacional de La Plata. Buenos Aires, República Argentina.

3 Ayudante Diplomado de Radiología y Fisioterapia de la Facultad de Odontología de la Universidad Nacional de La Plata. Buenos Aires, República Argentina.

4 Profesora Titular de Radiología y Fisioterapia de la Facultad de Odontología de la Universidad Nacional de La Plata. Buenos Aires, República Argentina.

\section{Correspondencia:}

Prof. Dr. Adrián Carlos Bencini

C/ Diagonal, 74 n² 2571 - 1900 Plata (Buenos Aires, República Argentina)

e-mail: adrianbencini@speedy.com.ar

\begin{abstract}
The aim of this study was to determine the type and magnitude of craniofacial asymmetry by multiplanar cephalometric analysis. The sample comprised 207 subjects of both sexes aged 18 to 22 years, who were radiographed in the frontal plane at posteroanterior incidence. Three separate acetate tracings were made on the same radiograph based on three planar structures: A (superficial), B (intermediate), C (deep). A virtual midline was traced. Real midlines were overlapped and compared with the virtual midline to determine the type and magnitude of the deviation on each plane.

The subjects were radiographed on the transverse plane. Three separate acetate tracings were made on the same radiograph based on three planar structures: A (orbital), B (maxillary superior), $C$ (maxillary inferior). A virtual midline was traced and compared with the real midline.

Frontal plane: Results indicated a greater frequency of right deviation in the three planes, $B$ being the plane with the largest percentage of deviation (type and magnitude) compared to $C$ and $A$. Transverse plane: Results indicated a greater frequency of left deviation in the three planes, $\mathrm{C}$ being the plane with the largest percentage of deviation (type and magnitude) compared to $B$ and $A$.

These results show that craniofacial asymmetry was widespread and emphasize the importance of its study in the detection of craniofacial growth pathology.
\end{abstract}

Key words: Asymmetry; Craniofacial; Deviation. 


\section{Introducción}

Esta demostrada la correspondencia entre la forma de la cabeza, la cara y las arcadas dentarias, a causa de la influencia de factores genéticos que determinan no solo esta relación sino muchas otras típicas de los seres humanos, como la longitud de los miembros superiores e inferiores, la forma de la arcada y de los dientes entre otras. Sin embargo, durante el crecimiento, pueden aparecer influencias desfavorables que lo alteran provocando variaciones notables en la forma y el tamaño de los diferentes tejidos y órganos involucrados. ${ }^{1}$

La dinámica del desarrollo craneofacial y las variaciones normales en el crecimiento de los maxilares, con el consiguiente desarrollo dentoalveolar, necesita ser comprendida antes de planificar o realizar cualquier tratamiento, mucho más si consideramos que la mayoría de los tratamientos se comienzan en etapas muy activas del crecimiento general y específicamente craneofacial. ${ }^{2}$ Tanto la mandíbula como el maxilar superior muestran con frecuencia desviaciones significativas con respecto a la configuración y posición normales. ${ }^{3-6}$ Existen factores del desarrollo que actúan recíprocamente, así como también los hábitos neuromusculares que provocan alteración en la armonía de las estructuras craneofaciales. 7,8

El diagnóstico del origen de las asimetrías craneofaciales es de fundamental importancia en la planificación de los tratamientos de las mismas, ya que éstas pueden ser originadas en problemas dentales o esqueletales. Las asimetrías esqueletales pueden ser enmascaradas por una compensación natural a través de la instalación de asimetrías dentarias. ${ }^{9}$

\section{Objetivos}

Analizar la morfología craneofacial de individuos de ambos sexos comprendidos entre 18 y 22 años de edad a fin de determinar la existencia de asimetrías craneofaciales anteroposteriores y basales $y$, en caso positivo, el plano y lateralidad en que se manifiestan, empleando análisis cefalométrico de planos múltiples.

\section{Material y método}

Se trabajó con una muestra de 207 individuos de ambos sexos de 18 a 22 años (Tabla 1), que fueron radiografiados:

A) En plano frontal con incidencia postero-anterior. Sobre cada radiografía se realizaron tres calcos tomando como referencia estructuras en tres planos diferentes: A (superficial), B (medio) y C

\section{Introduction}

The correspondence between the shape of the head, face, and dental arches has been demonstrated. It is due to the influence of genetic factors that determine not only this relation but many other relations typical of human beings, such as the length of the upper and lower limbs, and the form of the dental arches and teeth, among others. However, during growth, unfavorable influences can appear that may alter growth, causing notable variations in the form and size of the different tissues and organs involved. 1

The dynamics of craniofacial development and normal variations in the growth of the jaws with the consequent dentoalveolar development need to be understood before planning or performing any treatment, particularly if we consider that most treatments begin in very active stages of general and specifically craniofacial growth. ${ }^{2}$ The mandible and the maxilla both frequently exhibit significant deviations with respect to the normal configuration and position. 3-6 Development factors act reciprocally in conjunction with neuromuscular habits that cause alterations in the harmony of craniofacial structures. 7,8

The diagnosis of the origin of craniofacial asymmetries is of fundamental importance in planning their treatment because these asymmetries may arise from dental or skeletal problems. Skeletal asymmetries can be masked by natural compensation in the form of the development of dental asymmetries. ${ }^{9}$

\section{Objectives}

To analyze the craniofacial morphology of subjects aged 18 to 22 years of both sexes in order to determine the existence of anteroposterior and transverse craniofacial asymmetries and, if present, the plane and side where they occur using multiplanar cephalometric analysis.

\section{Material and Method}

The study sample consisted of 207 subjects of both sexes, aged 18 to 22 years (Table 1), who underwent radiography:

A. Frontal plane at posteroanterior incidence. Three tracings were made from each radiograph, taking as refer- 
(profundo). En cada radiografía se trazó una línea media virtual que cruza el punto medio de la distancia biparietal y la intersección entre la Crista Galli y la lámina cribiforme del etmoides. Sobre cada calco se realizaron cefalogramas, trazando las distancias entre estructuras bilaterales en cuyo punto medio se determino la línea media real para cada plano. Las líneas medias reales fueron superpuestas comparadas con la línea media virtual, determinándose así la dirección de la desviación en cada plano.

B) En plano basal. Sobre cada radiografía se realizaron tres calcos tomando como referencia estructuras en tres planos diferentes: A (orbital), B (maxilar) y C (mandibular). En el primer trazado, se construyó un triángulo uniendo dos puntos sobre los trígonos retromolares inferiores y el punto medio de los incisivos centrales inferiores. En el segundo trazado se construyó un triángulo semejante al descripto para el primer trazado, en el maxilar superior, uniendo dos puntos en las tuberosidades y un punto medio de los incisivos centrales superiores. En el tercer trazado se construyó un triángulo semejante a los anteriores cuyos puntos se establecieron en el centro de las órbitas y la apófisis Crista Galli. Sobre cada radiografía se trazó una línea media virtual que va desde el vértice del triángulo del tercer trazado, coincidiendo con la parte media del foramen mágnum y el punto medio de la protuberancia occipital interna.

\section{Resultados}

A. Frontales: El porcentaje de asimetría en la muestra total correspondió a 76,33\%, de ellas el $7,6 \%$ fueron solo derechas, el 1,26\% solo izquierdas y el 91,14\% de manera bilateral (Tabla 2). El análisis por edad y sexo
Tabla 2. Porcentaje de individuos con y sin asimetría en el plano frontal

$\begin{array}{lc}\text { Sin asimetría } & \mathbf{2 3 , 6 7} \\ \text { Con asimetría } & \mathbf{7 6 , 3 3} \\ \text { Lateralidad derecha } & \mathbf{7 , 6} \\ \text { Lateralidad izquierda } & 1,26 \\ \text { Bilateralidad } & 91,14\end{array}$

Table 2. Percentage of subjects with and without asymmetry in the frontal plane.

$\begin{array}{lc}\text { No asymmetry } & \mathbf{2 3 , 6 7} \\ \text { Asymmetry } & 76,33 \\ \text { Right side } & 7,6 \\ \text { Left side } & 1,26 \\ \text { Bilateral } & 91,14\end{array}$

ence structures in three different planes: $A$ (superficial), B (intermediate), and C (deep). A virtual midline was drawn on each radiograph that passed through the midpoint of the biparietal distance and the intersection between the crista galli and cribiform plate of the ethmoid. Cephalograms were made on each tracing, marking the distances between bilateral structures and using the midpoint between them to determine the true midpoint for each plane. The real midlines were superimposed and compared with the virtual midline to determine the direc-

Tabla 3. Porcentaje de individuos con y sin asimetría en el plano frontal

\begin{tabular}{|c|c|c|c|c|c|c|}
\hline \multirow[t]{2}{*}{ Variable } & \multicolumn{5}{|c|}{ Edad } & \multirow[t]{2}{*}{ Total } \\
\hline & 18 & 19 & 20 & 21 & 22 & \\
\hline \multicolumn{7}{|l|}{ Varones } \\
\hline Plano A derecha & 4 & 3 & 4 & 6 & 4 & 21 \\
\hline Plano A izquierda & 0 & 1 & 1 & 2 & 2 & 6 \\
\hline Plano B derecha & 7 & 10 & 12 & 11 & 9 & 49 \\
\hline Plano B izquierda & 5 & 4 & 2 & 3 & 5 & 19 \\
\hline Plano C derecha & 8 & 4 & 6 & 9 & 9 & 36 \\
\hline Plano C izquierda & 3 & 7 & 2 & 2 & 2 & 16 \\
\hline \multicolumn{7}{|l|}{ Mujeres } \\
\hline Plano A derecha & 2 & 4 & 4 & 0 & 8 & 18 \\
\hline Plano A izquierda & 1 & 1 & 1 & 2 & 1 & 6 \\
\hline Plano B derecha & 7 & 5 & 3 & 6 & 6 & 27 \\
\hline Plano B izquierda & 4 & 3 & 3 & 6 & 8 & 24 \\
\hline Plano C derecha & 7 & 6 & 6 & 3 & 6 & 28 \\
\hline Plano C izquierda & 3 & 1 & 0 & 2 & 6 & 12 \\
\hline
\end{tabular}

Table 3. Presence of asymmetry in the frontal plane by age and sex

\begin{tabular}{lcccccc} 
Variable & \multicolumn{7}{c}{ Age } & & Tota \\
& 18 & 19 & 20 & 21 & 22 & \\
Men & & & & & & \\
Right plane A & 4 & 3 & 4 & 6 & 4 & 21 \\
Left plane A & 0 & 1 & 1 & 2 & 2 & 6 \\
Right plane B & 7 & 10 & 12 & 11 & 9 & 49 \\
Left plane B & 5 & 4 & 2 & 3 & 5 & 19 \\
Right plane C & 8 & 4 & 6 & 9 & 9 & 36 \\
Left plane C & 3 & 7 & 2 & 2 & 2 & 16 \\
Women & & & & & & \\
Right plane A & 2 & 4 & 4 & 0 & 8 & 18 \\
Left plane A & 1 & 1 & 1 & 2 & 1 & 6 \\
Right plane B & 7 & 5 & 3 & 6 & 6 & 27 \\
Left plane B & 4 & 3 & 3 & 6 & 8 & 24 \\
Right plane C & 7 & 6 & 6 & 3 & 6 & 28 \\
Left plane C & 3 & 1 & 0 & 2 & 6 & 12
\end{tabular}
tion of the deviation in each plane.

B. Transverse plane. Three tracings were made from each radiograph, taking as reference structures in three different planes: $A$ (orbital), B (maxillary), and C (mandibular). In the first tracing, a triangle was constructed by joining two points on the lower retromolar trigone with the midpoint of the lower central incisors. In the second tracing, a triangle similar to the one described in the first tracing was constructed in the upper maxilla by joining two points in the tuberosities with the midpoint of the upper central incisors. In the third tracing, a triangle similar to the previous ones was constructed with the vertices set in the center of the orbits and the crista galli ridge. A virtual midline was drawn on each radiograph that extended 
indicó una tendencia uniforme en la edad en que se presentan las asimetrías, ligeramente más frecuentes en varones que en mujeres (Tabla 3).

En los varones correspondió: $47 \%$ al plano B, 35\% en el $\mathrm{C}$ y $18 \%$ en al $\mathrm{A}$ (Fig. 1A). En mujeres: el $44 \%$ plano B, en el C 35\% y en el A 21\% (Fig. 1B). Cuando se analizó la frecuencia por plano y lateralidad, el mayor número de individuos masculinos correspondió al plano B derecha, seguida por $C$ derecha $y$ por último A derecha. En mujeres en cambio, la mayor frecuencia correspondió a C derecha, B derecha, B izquierda y por último $\mathrm{A}$ derecha (Figs. $2 \mathrm{~A}$ y B).

Algunos individuos, tanto varones como mujeres, presentaron asimetrías en más de un plano. De un total de 100 varones, el $14 \%$ no presentaron asimetrías, 38\% presentaron asimetrías en un solo plano, en dos planos el $35 \%$ y $13 \%$ en los tres planos. En tanto que de las 107 mujeres, 35 $(32,7 \%)$ no presentaron asimetrías, en un plano presentaron 39 (36,4\%), $23(21,5 \%)$ en dos planos y en los tres planos $10(9,4 \%)$ (Figs. 3A y B).

B. Basales: El porcentaje de asimetría en la muestra total correspondió a 54,10\%, 60 varones y 52 mujeres. El análisis por edad y sexo indicó una tendencia uniforme en la edad en que se presentan las asimetrías, ligeramente más frecuentes en varones que en mujeres (Tabla 4).En los varones correspondió: $45 \%$ al plano C, $41 \%$ en el B y $14 \%$ al A (Fig. 4A). En mujeres: el 51\% plano C, en el B 46\% y en el A 3\% (Fig. 4B). Cuando se analizó la frecuencia por plano y lateralidad, el mayor número de individuos masculinos correspondió al plano C izquierda, seguida por B izquierda. En mujeres la mayor frecuencia correspondió a los planos B y C izquierda (Figs. 5A y B). La lateralidad izquierda fue más frecuente registrándose en 107 individuos $(77,53 \%)$, en $65(47,10 \%)$ fue a la derecha.

De un total de 100 varones, 40 (40\%) no presentaron asimetrías, $34 \%$ presentaron asimetrías en un solo plano, en dos planos el $20 \%$ y $6 \%$ en los tres planos. En tanto que de las 107 mujeres, from the vertex of the triangle of the third tracing and coincided with the middle part of the foramen magnum and the midpoint of the internal occipital protuberance.

\section{Results}

A. Frontal planes: The frequency of asymmetry in the total sample was $76.33, \%$, of which $7.6 \%$ was only on the right side, $1.26 \%$ only on the left side, and 91.14\% bilateral (Table 2). Analysis by age and sex indicated a uniform tendency in the age at which the asymmetry occurred and a slightly higher frequency in men than in women (Table 3).

In men the asymmetry was: $47 \%$ in plane B, $35 \%$ in plane $C$, and $18 \%$ in plane $A$ (Fig. 1A). In women: $44 \%$ in plane $B, 35 \%$ in plane $C$, and $21 \%$ in plane $A$ (Fig. 1B). When the frequency by plane and side was analyzed, a larger number of male subjects had asymmetries in the right plane $B$, followed by the right plane $C$, and, finally, the right plane A. In contrast, in women the most frequent asymmetries were in the right $C$ plane, right $B$ plane, left $B$ plane, and finally the right plane A (Fig. $2 A$ and B).

Some men and women subjects presented asymmetry in more than one plane. Of a total of 100 men, 14\% did not present asymmetry, 38\% had asymmetry in only one plane, $35 \%$ in two planes, and $13 \%$ in all three planes. Of the 107 women, there was no asymmetry in 35 (32.7\%) and 39 (36.4\%) had asymmetry in one plane, $23(21.5 \%)$ in two planes, and $10(9.4 \%)$ in three planes (Fig. $3 A$ and $B$ ).

$B$. Transverse planes: The percentage of subjects with asymmetry in the total sample was 54.10\%, 60 men and 52 women. Analysis by age and sex indicated a uniform tendency in the age at which the asymmetry appears and 
$55(51,4 \%)$ no presentaron asimetrías, en un plano presentaron $30(28 \%), 21$ $(19,7 \%)$ en dos planos y en los 3 planos $1(0,9 \%)$ (Figs. 6A y B).

\section{Discusión}

La mayoría de los estudios sobre crecimiento implican mediciones de huesos. Lo cual es comprensible dado que el hueso es sólido y radiopaco y, por lo tanto, más favorable para medir. Antiguamente los estudios cefalométricos longitudinales de Broadbent (Broadbent 1937) y Brodie (Brodie, 1941) les condujeron a pensar que el patrón normal de crecimiento facial y craneal ocurría como una unidad y era de forma estable. Los patrones óseos del esqueleto eran considerados como predeterminados y se pensaba que los cambios que acompañaban la corrección de mal oclusiones estaban restringidos a procesos alveolares (Graver, 1972). Luego los estudios cefalométricos y anatómicos de Björk y Palling (1955), Björk (1955), Ricketts (1961), Moss y Salentjie (1971), Farkas y Munro (1987) y Enlow (1968, 1975), entre otros, mostraron que el concepto de constancia de proporciones en el crecimiento facial era erróneo. El patrón de crecimiento facial está sujeto a cambios. Mientras que la genética juega un papel fundamental en la determinación de la extensión y dirección del crecimiento, hay evidencia que las influencias ambientales pueden también alterar profundamente los patrones de crecimiento. Que los estudios de crecimiento usen planos cefalométricos de la cabeza, usualmente significa una superposición de trazados en las placas, usando puntos de referencia anatómicos relativamente estables, puntos o planos para medir la dirección y cantidad de crecimiento de los puntos de referencia del esqueleto y dentales menos estables. Moyers y otros (1979) expusieron sobre lo inapropiado de las cefalometrías convencionales y propusieron un método de rejillas (grillas). Para superar tal dificultad, Buschang y otros (1968) recomendaron el uso de técnicas de regresión polinómicas.

La norma basilar fue descripta por Schuller (1905) y posteriormente por Merril (1949). Berger (1964) propuso un método para alinear el plano basilar con el plano lateral y posteroanterior basa-

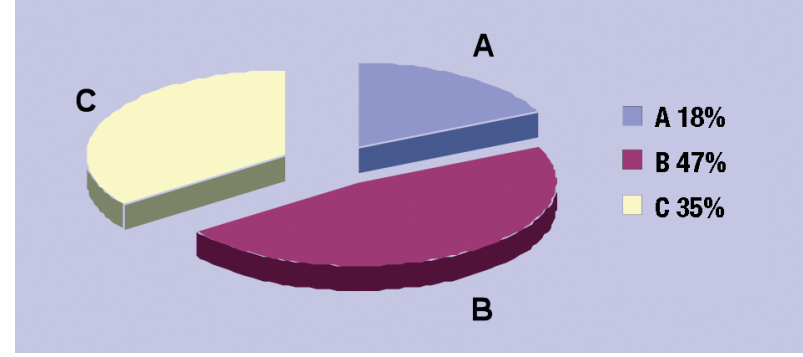

Figura 1A. Porcentaje de asimetrías por planos en varones. Figure 1A. Percentage of asmymmetry per plane in men.

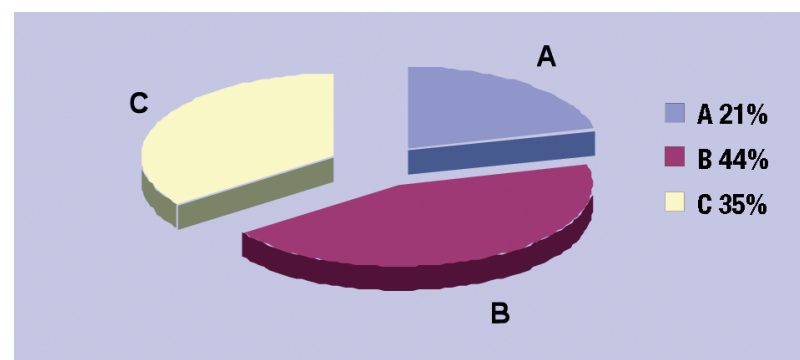

Figura 1B. Porcentaje de asimetrías por planos en mujeres. Figure $1 \mathrm{~B}$. Percentage of asmymmetry per plane in women.

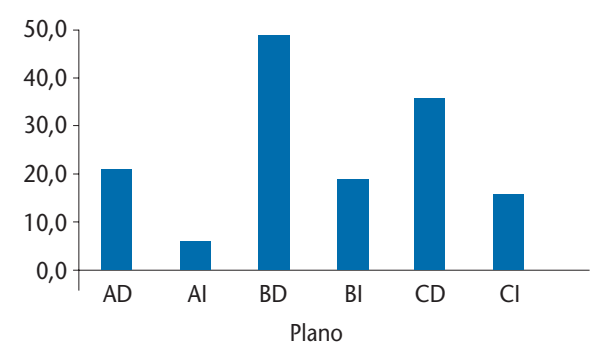

Figura 2A. Asimetría por plano y Lateralidad en varones. Figure 2A. Asmymmetry per plane and side in men.

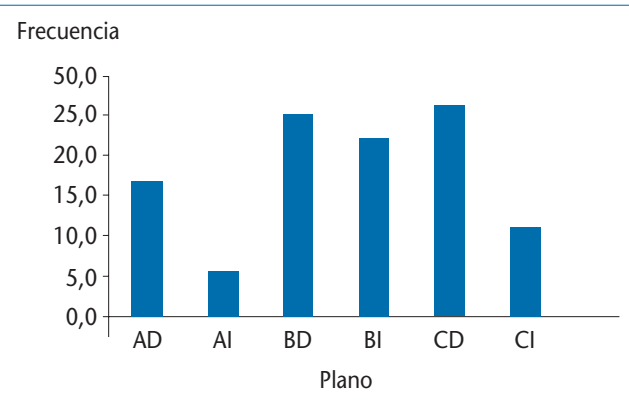

Figura 2B. Asimetría por plano y Lateralidad en mujeres. Figure $2 \mathrm{~B}$. Asmymmetry per plane and side in women. a slightly higher frequency in men than in women (Table 4). In men, $45 \%$ of asymmetry was in plane C, $41 \%$ in plane $B$, and $14 \%$ in plane $A$ (Fig. $4 A)$. In women, $51 \%$ of asymmetry was in plane $C, 46 \%$ in plane $B$, and $3 \%$ in plane $A$ (Fig. 4B). When the frequency was analyzed by plane and side, the largest number of asymmetries in men was in left plane $C$, followed by left plane $B$. In women, the highest frequency of asymmetries was in left plane $B$, followed by plane $C$ (Fig. 5 A and B). Asymmetry was found most frequently on the left side, with 107 subjects (77.53\%), versus the right ride, with 65 (47.10\%).

Of a total of 100 men, $40 \%$ did not present asymmetry, $34 \%$ had asymmetry in only one plane, $20 \%$ in two planes, and $6 \%$ in all three planes. Of the 107 women, there was no asymmetry in 55 (51.4\%) and 30 (28\%) had asymmetry in one plane, 21 (19.7\%) in two planes, and $3(0.9 \%)$ in three planes (Fig. $6 \mathrm{~A}$ and $B$ ).

\section{Discussion}

Most studies on growth involve measurements of bones. This is comprehensible because bone is solid and radiopaque and, therefore, easier to measure. The longitudinal cephalometric studies of Broadbent (1937) and Brodie (1941) lead them to think that the normal pattern of facial and cranial growth was as a unit and in a stable way. Skeletal bone growth patterns were considered to be predetermined and it was thought that the changes that accompanied the correction of bad bite were restricted to the alveolar processes (Graver, 1972). Later, the cephalometric and anatomic studies of Björk and Palling (1955), Björk (1955), Ricketts (1961), Moss and Salentjie (1971), Farkas and 
do en el plano de Francfort como un factor común. Este autor informó de un método para la determinación del plano basilar mediante el trazado de una línea a través del vómer, la parte posterior del septum nasal y la apófisis Crista Galli. Nahoum y cols. (1964) describieron una técnica para orientar las estructuras en los planos lateral, posteroanterior y basilar empleando los trazados de las proyecciones tridimensionales a un plano. Marmary et. al (1979) propusieron que la línea media podría ser derivada del estudio de la foramina neural en la base del cráneo la cual se considera tener escasa influencia ambiental. Estos estudios puntualizaron el valor de la construcción de la línea media en el plano basilar para la evaluación de las asimetrías en el esqueleto craneofacial.

Nuestro conocimiento y comprensión del crecimiento se han incrementado en los últimos años, de cualquier modo la ciencia aún no ha progresado a tal punto en biología, como para que los procesos de crecimiento puedan ser anticipados. Nosotros pensamos que el análisis radiográfico en el plano basal y frontal con incidencia posteroanterior ayuda al observador a visualizar las distintas regiones del complejo craneofacial a fin de comprender la deformación de las estructuras desde la simetría.

\section{Conclusiones}

Los resultados obtenidos permiten concluir que:

- El $76 \%$ de los individuos entre 18 y 22 años presenta algún tipo de asimetría en el plano frontal, siendo las de presencia bilateral más frecuentes.

- El 54,10\% presenta algún tipo de asimetría en el plano basal.

- Los varones muestran mayor porcentaje de asimetrías que las mujeres.

- No hay relación consistente entre frecuencia de asimetría y edad.

- En el plano frontal las frecuencias de asimetrías es mayor en el medio, seguido por el profundo y por último el superficial.

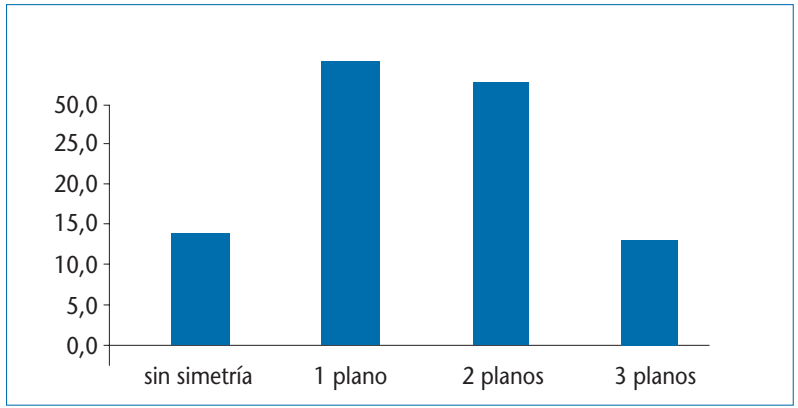

Figura 3A. Varones: Discriminación por planos afectados. Figure 3A. Men: discrimination per planes affected

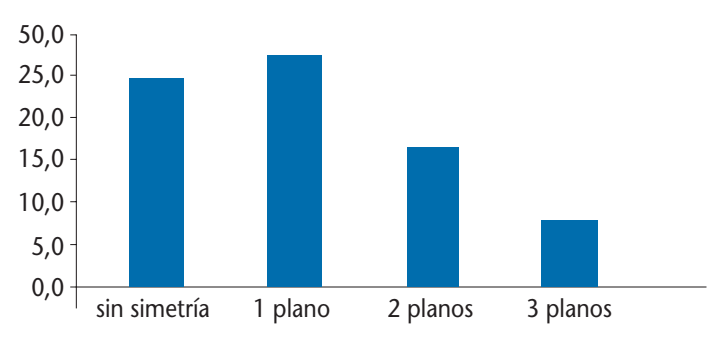

Figura 3B. Mujeres: Discriminación por planos afectados. Figure 3B. Women: discrimination per planes affected

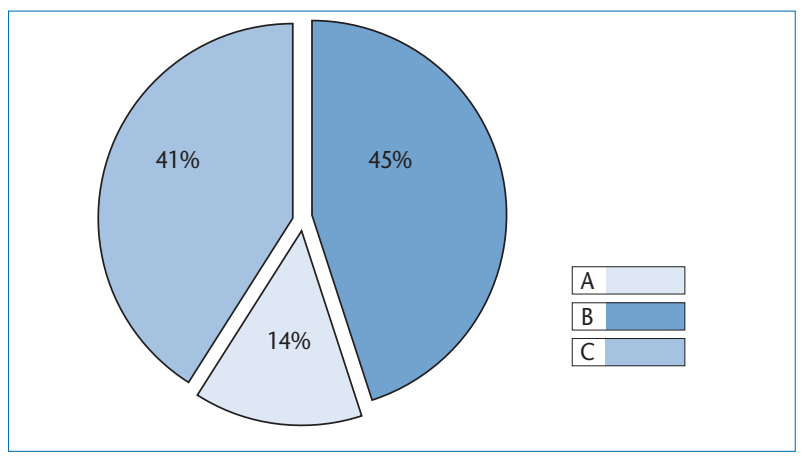

Figura 4A. Distribución por planos en varones. Figure 4A. Distribution per plane in men.

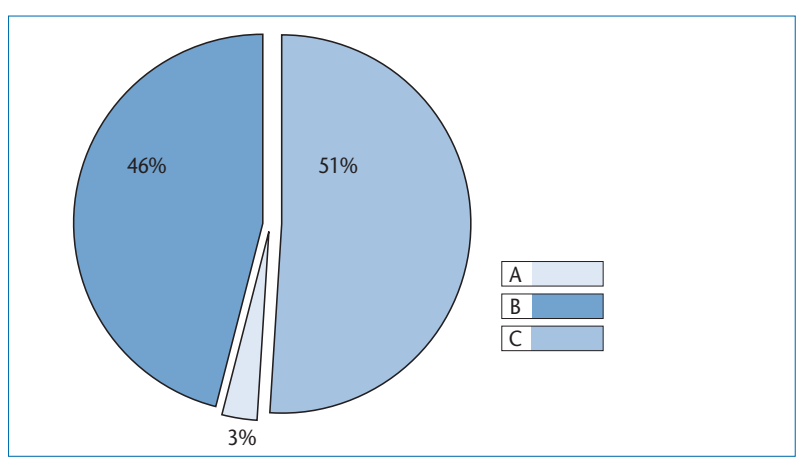

Figura 4B. Distribución por planos en mujeres.

Figure 4B. Distribution per plane in women.
Munro (1987), and Enlow (1968, 1975), among others, showed that the idea that proportions remain constant during facial growth was erroneous. The pattern of facial growth is subject to changes. Whereas genetics plays a fundamental role in determining the extension and direction of growth, there is evidence that environmental influences also can profoundly alter growth patterns. The general use of cephalometric planes of the head in growth studies usually involves superimposing tracings on radiographic films using relatively stable anatomic reference points and less stable points or planes for measuring the direction and amount of growth of the reference points of the skeleton and teeth. Moyers et al. (1979) discussed how inappropriate conventional cephalometry is and proposed the use of a grid method. In order to overcome this difficulty, Buschang et al. (1968) recommended the use of polynomial regression techniques.

The basilar norm was described later by Schuller (1905) and then by Merril (1949). Berger (1964) proposed a method for aligning the basilar plane with the lateral and posteroanterior planes based on the Frankfurt plane as a common factor. This author informed of a method for the determination of the basilar plane by drawing a line through the vomer, the posterior part of the nasal septum, and the crista galli ridge. Nahoum et al. (1964) described a technique for orienting the structures in the lateral, posteroanterior, and basilar planes using tracings of three-dimensional projections on a plane. Marmary et al. (1979) proposed that the midline could be derived from the study of the neural foramina in the skull base, which are con- 
- En el plano basal las frecuencias de asimetrías es mayor en el mandibular, seguido por el maxilar y por último el orbital.

- En el plano frontal $28 \%$ de los individuos presenta asimetrías en dos planos, en el basal 36,6\%.

- La lateralidad derecha es la más preponderante en el plano frontal y la lateralidad izquierda en el basal.

\section{Bibliografía}

1. Cusminsky $M$, Lejarraga $H$, Mercer R, Martell M, Fescina R. Crecimiento: enfoque conceptual. En: Manual de crecimiento y desarrollo del niño. 2 ed. Washington DC: OPS, 1994;1-6.

2. Jordan J, Bebelagna A, Rubén M, Hernández J. Investigación sobre crecimiento y desarrollo. Cuba, 1972 - 1974. Rev Cubana Pediatr 1977; 49:367-90.

3. Reihardson A. A Classification of open bites. Eur J Orthod 1991;13:287-96.

4. Mizrali E. A review of anterior open bite. $\mathrm{Br}$ J Orthod 1988;15:21-7.

5. Poswillo DE. Early pulp changes following reduction of open bite by segmental surgery. Int Oral Surgery 1999;11:387-92.

6. Gjorop $\mathrm{H}$, Athanasiow AE. Soft-tissue and dentoskeletal profile changes associated with mandibular setback osteotomy. Am J Orthod Dentofac Orthop 1991;100:312-23.

7. Berge MG. Team rapport: its value in surgical orthodontics. J Oral Surg 1990; 47:23741.

8. Bauson DE. Salving anterior open bite problem. En: Evaluation diagnosis and treatment of oclusal problems. St. Louis; CV Mosby, 1991;322 -30 .

9. Burstone CJ. Diagnosis and treatment planning of patients with asymmetries 1998;4:15364 .

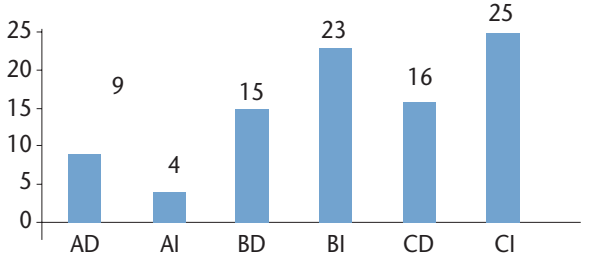

Figura 5A. Varones: distribución por plano y lateralidad. Figure 5A. Men: distribution per plane ans side.

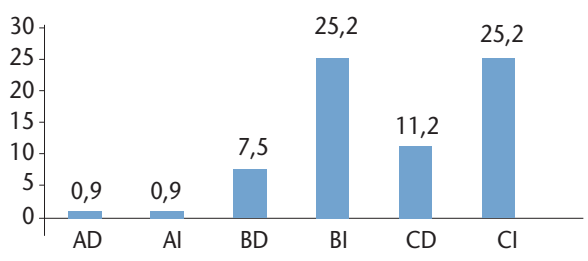

Figura 5B. Mujeres: distribución por plano y lateralidad. Figure 5B. Womne: distribution per plane ans side.

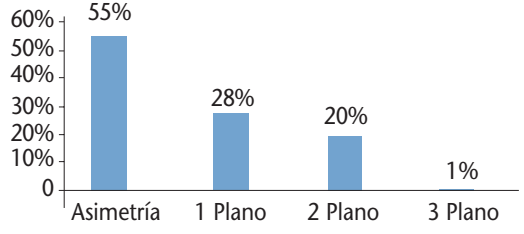

Figura 6B. Mujeres: distribución por plano. Figure 6B. Women: distribution per plane.

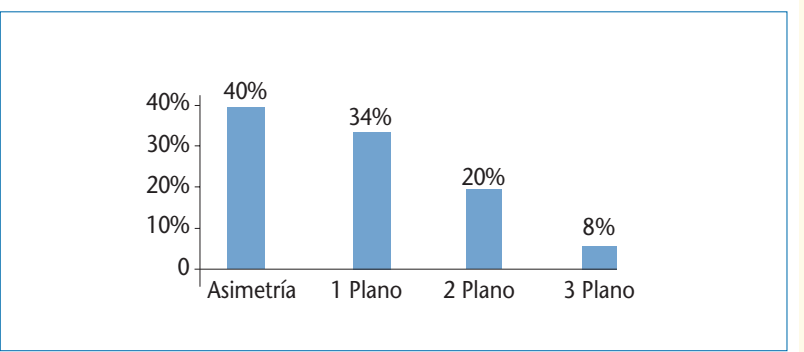

Figura 6A. Varones: distribución por plano.

Figure 6A. Men: distribution per plane. sidered to have little environmental influence. These studies emphasize the value of constructing the midline in the basilar plane to evaluate asymmetries in the craniofacial skeleton.

Our knowledge and understanding of growth have increased in recent years, but science has not yet progressed to such a point in biology that growth processes can be anticipated. We think that radiographic analysis in the transverse plane and frontal plane at posteroanterior incidence help the observer to visualize the different regions of the craniofacial complex in order to understand the deformation of structures from symmetry.

\section{Conclusions}

The results obtained allow us to conclude that:

- Some type of asymmetry on the frontal plane was present in $76 \%$ of the subjects aged 18 to 22 years; bilateral asymmetries were the most frequent.

- Some type of asymmetry in the transverse plane was present in $54.10 \%$.

- Men showed a greater percentage of asymmetry than women.

- There was no consistent relation between the frequency of asymmetry and age.

- In the frontal plane, the frequencies of asymmetry were higher in the intermediate plane, followed by the deep plane and then the superficial plane.

- In the transverse plane, the frequencies of asymmetry were higher in the mandibular plane, followed by the maxillary and then the orbital plane.

- In the frontal plane, $28 \%$ of the subjects presented asymmetry in two planes, $36.6 \%$ in the transverse plane.

- The right side was predominant in the frontal plane and the left side was predominant in the transverse plane. 